\begin{tabular}{|l|l|l|l|l|}
\hline \multirow{2}{*}{ a $1>1$ DPta } & CUAN & cuan_1153 & Dispatch: June 13, 2012 & CE: N/A \\
\cline { 2 - 5 } & Journal & MSP No. & No. of pages: 16 & PE: Sarah \\
\hline
\end{tabular}

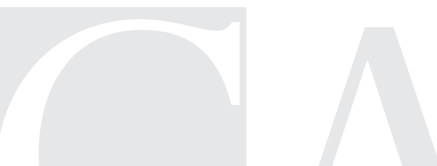

\title{
ETHNOGRAPHY IN LATE INDUSTRIALISM
}

\author{
KIM FORTUN \\ Rensselaer Polytechnic Institute
}

Think about the timing. The 1984 Bhopal disaster-marking the risks of industrial order, and the already degraded state of industrial infrastructure. The "American" plant in central India was underdesigned for safety, and had not been maintained. The 40-ton tank that released its contents into the air of a sleeping city on December 3, 1984, is where the many failures of many involved systems came together, at a boil (Fortun 2001). ${ }^{1}$ Thousands were killed; hundreds of thousands of others were exposed, their bodies becoming even more laced with toxics than mine, yours, and all others in our late industrial age. Understanding of the chemicals released in Bhopal remains inconclusive; they are among the over 100,000 chemicals registered with governments around the world for routine use; the data hasn't been collected, the science hasn't been done, to understand how these chemicals affect human and ecosystem health. Thousands of new chemicals continue to be introduced each year (see Figure 1). ${ }^{2}$

The Bhopal plant site today is decrepit and eerie. The old control room is open air and crumbling. The old piping configuration still stands, rusted; former Union Carbide worker T. R. Chouhan can still narrate its workings, pointing out the pathways and junctures leading to the reaction in Tank $610 .{ }^{3}$ On the perimeter of the site, an old waste disposal site still oozes chemicals (Centre for Science and the Environment [CSE] 2009). The smell is truly worse than shit. It is the smell of late industrialism. Children play and cows graze within it (see Figure 2).

CULTURAL ANTHROPOLOGY, Vol. 27, Issue 3, pp. 446-464. ISSN 0886-7356, online ISSN 1548-1360. (c) 2012 by the American Anthropological Association. All rights reserved. DOI: 10.1111/j.1548-1360.2012.01153.x 


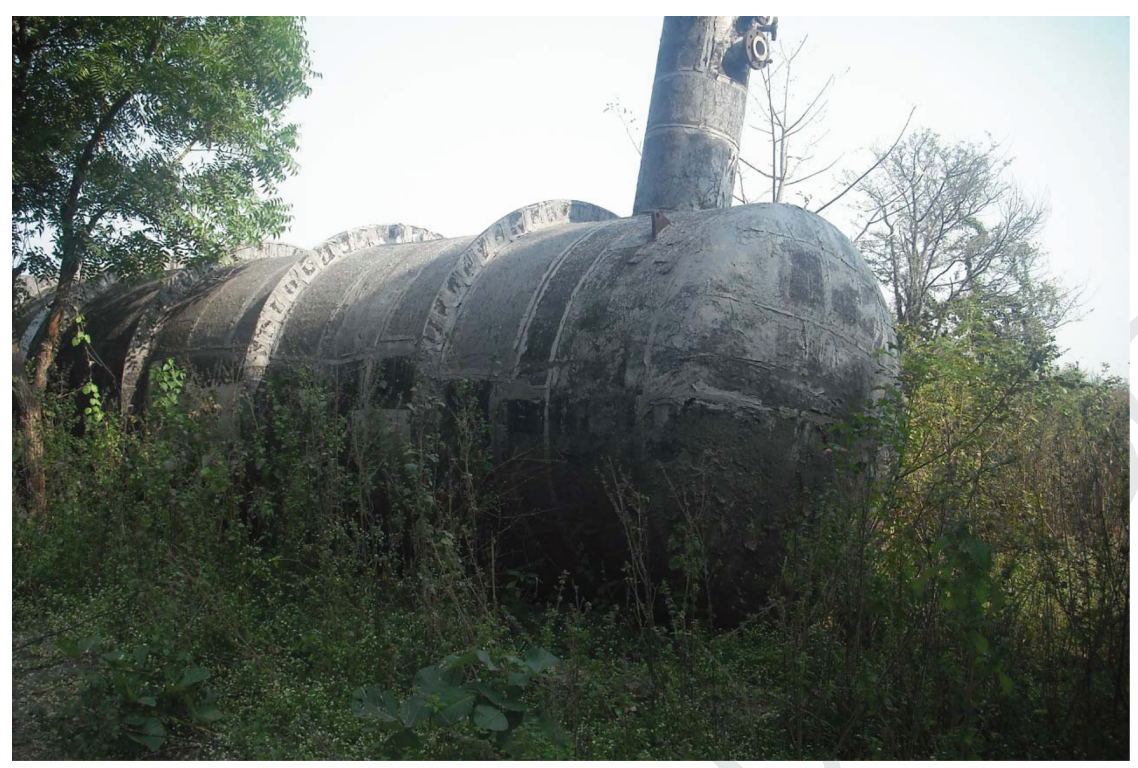

FIGURE 1. Tank 610 at the old Union Carbide plant in Bhopal India. Forty tons of toxic methyl isocyanate were released from this tank in the early morning hours of December 3, 1984.

Zoom out to picture Delhi. New, gated communities house a multinational corporate elite. The future they work for, that they have anteriorized, is that promised and motored by neoliberalism, bolstered by digital infrastructure and wealth but still energized by coal and oil. There are many more cars on the road. And increasing rates of asthma. People can't breath. Another sign of late industrialism (CSE 2011).

And people can't think. According to a survey of “American Environmental Values" sponsored by the Sierra Club and other environmental organizations, Americans are paralyzed by issue complexity. The survey also reports that "libertarian values are ascendent over communal values” (SRI Consulting 2006). Complexity, but little collectivity. Not a great combination.

This is a world in which Clarence Thomas, former attorney for Monsanto, becomes a U.S. Supreme Court Justice. A world in which Iraqi farmers are told that they are required to plant "protected," crop varieties, defined as new, distinct, uniform and stable — as Monsanto seeds. Seed saving was made illegal; contracts to purchase herbicides, insecticides, and fertilizers were also required (Sourcewatch n.d.). The complexity of these conditions, the entanglements - of business and government, of law and politics, of war and farming, of natural and technical systems - is stunning, and sobering. 
cuan_1153 can2008.cls June 13, $2012 \quad 14: 14$
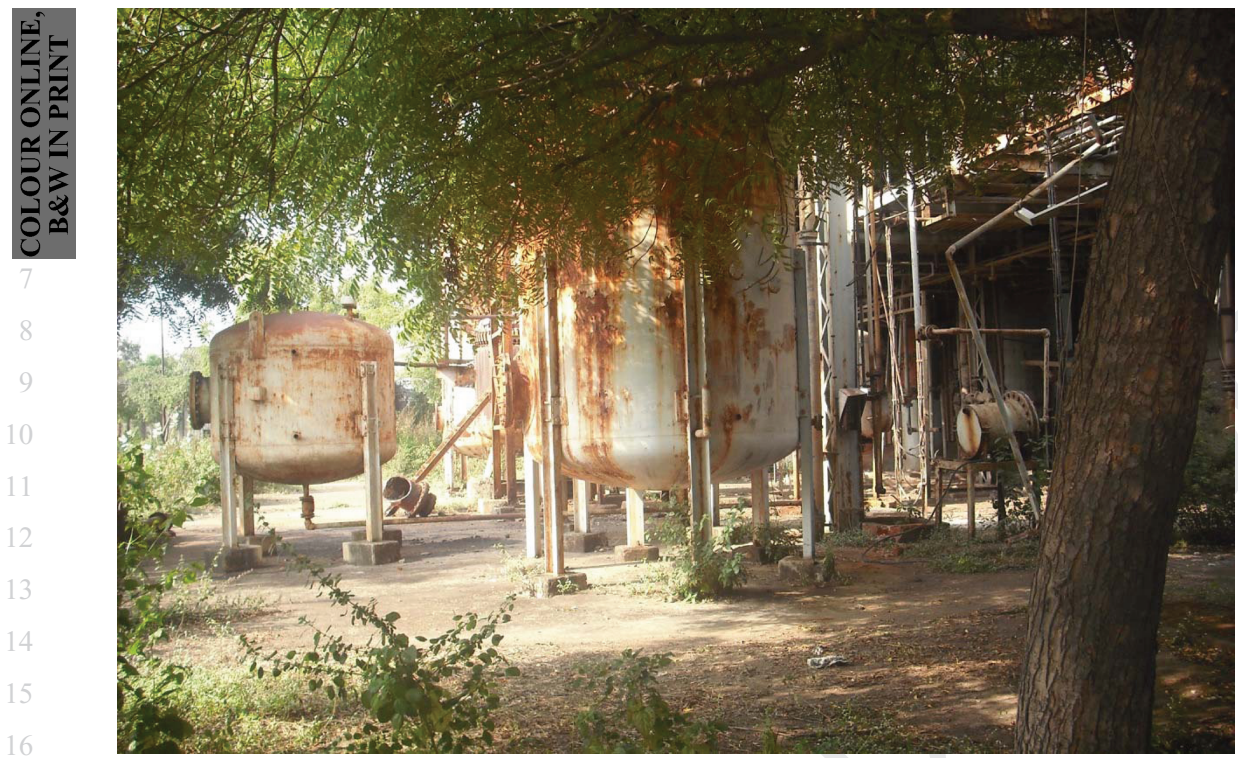

FIGURE 2. Degraded components of the Union Carbide pesticide plant in Bhopal, India. The site is now abandoned, but remains contaminated with pesticides, chlorinated benzenes, and heavy metals. Groundwater serving local communities is also contaminated.

This is late industrialism, where we've come since 1984.

Again, think about the timing: 1986, Clifford and Marcus's Writing Culture, a call to rethink thought - about anthropology and ethnography, authority and the purpose and responsibilities of scholarship. It was historically attuned, and a call to remain historically attuned, a call to always ask about the conditions in which ethnography is produced, and must work within, a call to recognize how discursive forms, including those of ethnography, stage, direct and limit, what is said and not said, who is heard and benefits, who and what remains subaltern, outside articulation. It embodied and animated what has become known as the "language turn" in the humanities and the human sciences.

The original critique was directed at the conceptual, discursive, and social forms of what could be called high industrialism. The concern was with discursive exclusion and the promise of polyvocalism, with ways around the disjuncture between dominant ways of understanding the world, and what ethnographers encountered on the ground.

How, today, do we both stay with and update the call? How, today, at a time when social order and sensibility are worked out on talk shows, a time in which we are Outfoxed (2004) by the news, and even the best of coverage insists on 
cuan_1153 can2008.cls June 13, $2012 \quad 14: 14$

"balance," granting equal time to those few who refuse to believe scientific evidence of climate change, working with constructs of fairness and appropriateness that embody simple to the point of simplistic notions of democracy and truth (Boykoff and Boykoff 2004).

It is also a world noisy with new media, streaming through products with planned obsolescence (Slade 2006). Cell phones and iPods last a year or two. In 2009, when broadcasters switched to digital TV signal, millions of analog TVs became garbage. Electronic waste piles up and circulates globally, leaching toxins into humans and animals, soil, air and water. ${ }^{4}$

The pipes that carry water to and waste away from households, hospitals, schools and businesses are now aging, even in metropoles like Washington, D.C. The D.C. sewer was built in 1889 . The average D.C. water pipe is 77 years old (Halsey 2012). Across the United States, water and sewage systems haven't been updated; they leak and overflow. ${ }^{5}$ And they have no way to deal with what now passes through them: water laced with runoff from roads and effluents from manufacturing plants, but also with pharmaceutical residues, including synthetic hormones (Zota 2010). Amphibians are the new canaries in the coal shaft, exhibiting skewed sexual development, and extra limbs (Lanoo 2008; Slater 2012). Queer, in a way that cannot be applauded.

And it is a world of even more experts. A world in which cadres of well trained men and women carry out highly specific functions that maintain the technical and economic conditions of our times. People specialize in very particular domains of production, spending their days immersed in the information flows and practices of biomedical care for asthma, of transportation engineering, of the design of convenience stores or shopping malls. There is incredible particularity, and incredible complexity. Incredible skill and pervasive deskilling. ${ }^{6}$

Much of the infrastructure, many of the paradigms that have held it up, are exhausted. Things are falling apart, again.

What is the task of ethnography at such a moment?

\section{QUESTIONS CONCERNING ETHNOGRAPHY}

The word technology comes from Greek $\tau \varepsilon \chi \nu_{0} \lambda o \gamma i \alpha$ (technología); from

$\tau$ é $\chi \nu \eta$ (téchnē), meaning “art, skill, craft," and - $\lambda$ o $\gamma i \alpha$ (-logía), meaning "study of-." 
cuan_1153 can2008.cls June 13, $2012 \quad 14: 14$

CULTURAL ANTHROPOLOGY 27:3

How can we leverage the affordances of ethnography to understand and engage a late industrial world? How, particularly, can we leverage understanding of how ethnography works as articulated in Writing Culture, in synch with a 1980s flurry of feminist and postcolonial criticism? What would make ethnography "appropriate" to the historical conditions in which we find ourselves today? What designs on/of ethnography should we cultivate? ${ }^{7}$

I write here — of leveraging, affordances, how things work, appropriateness and design - from within Science and Technology Studies, where many of us love, and love to study technology, understood expansively. Technology, from this vantage point, is something crafted to enable and direct, routing desire, making new things possible and possible to imagine. And it should, etymologically speaking, have an in-built reflexivity, a study of that which is crafted, and of how craft happens and should happen, that occurs alongside the making and use of the technology. ${ }^{8}$

Ethnography can be thought of as a technology in these terms, as a means through which things are enabled. And ethnography, like other technologies can be designed in different ways - to draw out what is, the state of things, or to show what is at odds with extent theory, ethnography as cultural critique (Marcus and Fischer 1986). Ethnography, like other technologies can also be designed to challenge and change existing order, provoking new orderings of subjectivity, society and culture, having what Steve Tyler, in Writing Culture, called a "therapeutic effect" (1986).

Thus far, it seems to me, we have made good use of ethnography for the first of these, for understanding, and critique. And critique, to be sure, is transformative. I don't at all mean to suggest that ethnography has "just" been critique. I do, however think there are new possibilities to pursue, directed at transformation, but without the teleological overtones of activism as usual.

Ethnography, I want to suggest, can be designed to bring forth a future anterior that is not calculable from what we now know, a future that surprises. Ethnography thus becomes creative, producing something that didn't exist before. Something beyond codified expert formulas.

The future is anteriorized when the past is folded into the way reality presents itself, setting up both the structures and the obligations of the future. The future inhabits the present, yet it also has not yet come - rather like the way toxics inhabit the bodies of those exposed, setting up the future but not yet manifest as disease, nor even as an origin from which a specific and known disease will come. Toxics, like the future anterior, call on us to think about determinism, but without the straightforward directives of teleology. 
cuan_1153 can2008.cls June 13, $2012 \quad 14: 14$

Derrida, rereading Levinas, reminds that the "future anterior could turn out to be - and this resemblance is irreducible - the time of Hegelian teleology. Indeed, that is how the properly philosophical intelligence is usually administered, in accord with what I called above the dominant interpretation of language - in which the philosophical interpretation precisely consists." Derrida also suggests other possibilities, describing how the concept of the future anterior could have "drawn us toward an eschatology without philosophical teleology, beyond it in any case, otherwise than it" (1991:36-37).

Derrida writes of the future anterior to think about what both demands and makes possible a future that would not merely be a continuation of the present. The future anterior, Derrida says, puts in place a "lace of obligation" that both binds and unbinds the ethical actor. The possibility of pursuing justice beyond the determinations of law is one important effect (Derrida 1990:329).

Biologists and historian of biology, and translator of Derrida, Hans Jorg Rheinberger can be read as describing how a future anterior is pursued in science, through the building of experimental systems. These systems are systems, carefully designed to work in a way that generates surprises. Experimental systems are not testing devices, designed to confirm what is already known. They are designed to allow for the emergence of questions that could not be asked before (Fischer 2007; Fortun 2003; Rheinberger 1998; Ronell 2005:45-48).

Ethnography, too, can be designed in such a way.

Partly because ethnography, historically, by definition, perhaps, certainly as articulated in Writing Culture, has affordances that call for openness to what is foreign, Other, not yet articulable (Bhaba 1994). It tolerates, indeed cultivates, open-endedness.

Ethnography also has a record and habit of shifting in concert with the times, responsive to both historical conditions and internal critique (of the sort Writing Culture offered). And these conditions can be discerned ethnographically. This is a critical step in the design process that I put forward here.

Ethnography, at its best, provides a powerful and efficient way to read historical conditions. It produces both situated and comparative insight, is able to see across scale, and leverage different analytic lenses. It can draw out nested and proximate systems, sensitive to their similarities, differences, and synergisms. Postcolonialism and neoliberalism, for example, can be seen as phenomena that cut across space in similar ways, and as phenomena that are exquisitely specific in their instantiations. The ability to recognize both is an ethnographic signature. So, too, with language games. The discursive dynamics that we observe and parse can be recognized as 
cuan_1153 can2008.cls June 13, $2012 \quad 14: 14$

CULTURAL ANTHROPOLOGY 27:3

those of modernity or "the Enlightenment" and Patriarchy, for example, and also as specific to particular problem domains, domains with particular information flows and practices, their own ways of making sense. Many such problem domains today, in our late industrial times, involve complex conditions, conditions involving many nested systems - technical, biophysical, cultural, economic - and thus a multiplicity of interactions, which keep the parameters of "the problem" from ever settling down. Complex conditions resist explanation in available terms, producing what I have come to think of as discursive gaps, and discursive risks.

Discursive gaps emerge when there are conditions to deal with for which there is no available idiom, no way of thinking that can grasp what is at hand.

Discursive risks emerge because of a tendency to rely on established idioms and ways of thinking, nonetheless.

As when the idioms and thought styles of mechanics are imposed on toxics, for example. The particular dynamics of toxics are then ignored. Ignorance is produced. We are continually told that "there is no evidence of harm to humans" because the evidence deemed necessary is at odds with the condition it is meant to represent. What is Other to the dominant idiom is colonized by it.

Another example is when water and other resource wars are cast as religious or ethnic wars. It may be that religion and ethnicity are part of the puzzle, but habits of reading in these terms produce ignorance about environmental determinations. ${ }^{9}$

Feminist theory has, of course, taught us much about this kind of cycle, and the violences of it. Ethnography can help break the cycle, leveraging its capacity to get at the exacting specificity of a given problem domain. This is critical in these times, late industrial times in which most problem domains are like the tightly coupled complex systems described by sociologist Charles Perrow in his seminal book Normal Accidents (1984). The industrial systems Perrow describes-nuclear power plants, chemical processing plants, air transport networks - are made of a tangle of technical systems, which are so tightly coupled that it must be considered "normal" to have runaway incidents that exceed what experts can understand, much less control. Ethnography has affordances that enable it to effectively observe and respond to this kind of dynamic, typical of the problem domains of late industrialism.

\section{DESIGNING ETHNOGRAPHY}

There are a number of steps in the design process.

First, and continuing, is the ethnographic work of discerning discursive 
cuan_1153 can2008.cls June 13, $2012 \quad 14: 14$

understand what is so, discursively, and materially. Again, feminist theory has laid ground. ${ }^{10}$ We need to understand what is said, what can be said, and what is disavowed.

This understanding, ironically, becomes something we can share, make into a collective resource, only by rendering it in terms of established idioms, which we know in advance are inadequate, even violent. This was a key teaching of Writing Culture. What we can think or say — even within and in the idiom of anthropologycannot but be within established systems of ideality. Thinking in terms of theory, even poetics, delimits us. So we must proceed with humility, humor, and reflexivity, reaching to move from the overdeterminations of description to provocation, knowing that we will have to design for something otherwise.

We must next loop, leveraging ethnography not only to describe what is at hand but also to respond to the discursive gaps we have come to see, and understand. ${ }^{11}$

Our task now becomes creative. We must try, through the design of an experimental ethnographic system, to provoke new idioms, new ways of thinking, which grasp and attend to current realities. Not knowing in advance what theses idioms will look and sound like.

Ethnography must, then, create a space for deliberation, for worrying through, for creativity. It must stage encounters. Operating a bit like performance art.

Readers thus become users of the systems we build; our interlocutors become party to what we say. Ethnography becomes polyvocal, as called for in Writing Culture, in a way that literally keeps the conversation going, and open. ${ }^{12}$

The goal is not to give everyone a chance to speak, as a matter of fairness. The model is not the town hall meeting or the talk show. But it is about being open to intervention and foreigners, about hospitality, and solicitude. ${ }^{13}$ The goal is to come together - to literally collaborate, performing the labor of difference, to articulate something that could not be said, could not be brought together before.

Let me provide a few examples of what this might look like:

\section{The Asthma Files}

First, a project that I have undertaken with a number of colleagues, which we call The Asthma Files. I want to highlight the ethnographic looping that I called for earlier - how insight from the research is being fed back into the design of the project, functioning as what we call "substantive logics," which operate alongside what we call "design logics," drawn from what is usually thought of as "theory." These substantive logics lay out the discursive habits, gaps, and risks of the problem 
cuan_1153 can2008.cls June 13, $2012 \quad 14: 14$

CULTURAL ANTHROPOLOGY 27:3

domain in which asthma operates, made up of overlapping systems and worlds. The worlds of epidemiology and pollution science, of biomedicine and school nurses, of young athletes and old women, of families in urban housing projects, and in rural households around the world in which cooking fuels generate an ever-present, eventually unnoticed but still debilitating smoke.

In studying these worlds, and their interactions, we have come to see patterns and habits, incapacity and incapability. A Lancet review in 2006, for example, questions whether asthma is an overly monolithic term, which glosses amazing variation in asthma occurrence. Operating at more of a micro level, a research group at the University of Texas Medical Branch at Galveston that focuses on severe, life threatening asthma, has recently changed directions, provoked by recognition that established understanding of who is at risk, and when, are simply wrong, or at least out of synch with the data if looked at through the lens of advanced informatics. In recategorizing people according to their "protein profiles," and correlating those to subsets of asthma severity, new research directions have opened up. ${ }^{14}$ Hesitations and shifts like these produce important openings for the kind of ethnographic encounter I want to help stage, encounters that would trouble established frameworks, facilitating slippage, so that new questions and idioms can emerge.

Such staging has to consider where the conversation is likely to go. The goal is not to give everyone a chance to voice his or her perspective, rearticulating what they think and see. The goal is create a space of creativity, where something surprising, something new to all emerges.

The ethnographer sets the stage accordingly. In dealing with asthma, many tendencies have to be diverted. First is the tendency to remain disassembled, such that the various parts never come together. Epidemiologists with large asthma cohort studies not knowing about air quality data sets maintained by state and federal government agencies, which they could draw into their analyses, at least attempting a reading a environmental determinations, for example. Another tendency is to hierarchically order the types of data and knowledge in play. Asthma geneticists, for example, reifying the types of data genomics is able to produce, with huge investments of time and expertise, such that the data produced by air chemists and chemical engineers, drawn from monitors along highways and atop schools, is never considered usable, always too noisy, not true enough to what a specific human body is exposed to and incorporates. A third tendency we actively work against is a tendency to locate care and cure in the biomedicalized, inhaler-ready, 
cuan_1153 can2008.cls June 13, $2012 \quad 14: 14$

out by very well meaning nurses, coaches, and parents; a teleology we want to displace.

So we have designed a web platform that supports collaboration among ethnographers working on various components of this puzzle, enabling a collective, multisited ethnography, which we try to keep intensely cross-linked. As the platform evolves, our interlocutors who work on asthma will be drawn in to the site itself so that they, too, like the ethnographers involved, are immersed in what we think about as a juxtapositional logic, a logic wherein divergent ways of seeing (often the same thing) are brought together. ${ }^{15}$ The structure of Bateson's Naven comes to mind here(1962); we want to draw out what one gets when one sees through different analytic lenses, from different vantage points. Not to resolve differences nor to merely celebrate diversity, but to provoke encounters across difference that produce new articulations.

This is requiring new kinds of discipline, the discipline to design and then work with ethnographic questions sufficiently standardized to allow juxtapositions to be animated. We query all of our interlocutors about the kinds of data they create, use, and idealize, for example. We also ask about their methodological anxieties, workarounds, and biases. There are about 30 questions we try to return to. These questions must be adhered to for the platform to really work. Forced methods, so to speak, with a critical intent akin to the "forced readings" that Gayatri Spivak showed us to be so productive (Spivak 1987, 1993).

Developments in the environmental health sciences have also taught me to be patient with this new discipline. It has only been through hard won standardization of the metadata on environmental health data sets that environmental health scientists have been able to push into being new ways of understanding and representing toxicity, regional air quality, nested ecosystems, and other objects of concern. Diversity of content and form has had to become interoperable (Fortun 2011). ${ }^{16}$

Our digital platform thus operates as both a research tool and as a space to share research results. We offer what we think of as staccato readings, short, densely cross-linked articulations that quickly move users elsewhere in the system, where they will see the puzzle from a different vantage point. The system is meant to provide a portal - a designed way in - to the world as it is, in its incredible complexity, while destabilizing usual ways of thinking about the world and its possibilities. So the goals are traditionally ethnographic, in a sense, but with creative intent.

What we want to stage is an encounter with asthma that anticipates discursive habits that pose discursive risks, mindful, too, of things that need to be articulated, 
cuan_1153 can2008.cls June 13, $2012 \quad 14: 14$

CULTURAL ANTHROPOLOGY 27:3

which don't yet have an idiom. Gene-environment interactions in asthma incidence, for example. The connection between air quality and health outcomes. We know in advance that conventional (scientific) constructs of causation won't suffice, so we try to animate other ways of making connections, and seeing relationships.

We thus loop, turning ethnographic findings back into the system, an experimental ethnographic system also designed to embody the theories of language that animated the so-called language turn of the 1980s. So it is both a legacy and emergent system, theoretically inflected and deeply ethnographic.

\section{Convenience Stores and the U.S. (Industrial) Food System}

The second project that I want to point to is even more emergent, and focused on a condition at least as complex as asthma - the U.S. food delivery system. The point of entry is the convenience store. Michael Powell, another anthropologist educated at Rice, is undertaking this project in the Los Angeles area, where he works for an architectural design firm that specializes in the planning of urban retail, advertising itself as a firm "with a focus on leveraging consumer perceptions." Much of his firm's work focuses on food retail, including supermarkets, restaurants, bodegas, and convenience stores. Through this, Powell has had access to food executives, marketers, cashiers, and customers. He has learned that there are nearly 150,000 convenience stores in the United States, constituting a $\$ 500$ billion industry, and that this industry knows it needs to rethink itself and the future. Partly because tobacco sales, which comprise a huge percentage of convenience store sales are declining. One type of convenience store also sells gas, which is also likely to move in different ways in coming years. But what will the convenience store of the future look like? Will today's convenience store remain? A small, well-lit box store that sells cigarettes and lotto tickets, coffee, slushees, and hotdogs off heated rollers on the counter, its shelves stocked with food from who knows where, laced with preservatives, bound up in plastic?

Is something else imaginable?

The food industry planners that Powell has interacted with through his firm want to innovate. And they know how to think about consumer perceptions, and how they can be shifted. But Powell has been struck by how little they know about other kinds of thinking about local and global food systems, their interconnections, and problems. It is not that his interlocutors are not expert; they are intensively expert, and thus operate in a manner and in a world that is delimited.

In Powell's experience, for example, many food industry experts have never 456 heard of Michael Pollan, a leading voice for people concerned about how healthy 
cuan_1153 can2008.cls June 13, $2012 \quad 14: 14$

today's food is, for people, ecosystems, and economies. There has been a surge of work critical of Food, Inc. and its factory farms, incredibly high food miles and unregulated ingredients. ${ }^{17}$ And a surge of interest in obesity and other indexes of food delivery systems gone wrong. But not in the world of the food industry itself.

What would happen if these worlds were brought together? One could predict where the conversation would likely go, based on ethnographic observation of the assumptions, binaries, and expectations of different players. It could well end in uncomfortable silence.

Could the ethnographer stage something different, a carefully designed encounter intended to provoke what neither "side" could say or imagine coming in?

Where should the event take place? What questions should be posed? What solicitation techniques could be used? How could an ethnographic understanding of the ways language and meaning work be put to work?

Michael Power is now wrestling with all this. I challenge you, too, to think in these terms - about how the food industry, and its critics, could be shaken up, but also about ethnography in an array of other problem domains that, in a tightly coupled way, make up late industrialism.

\section{IN THE FUTURE}

What we are after here could be called the différend, or jouissance. We want to reach beyond established systems of ideality, where Derrida and Levinas locate justice. Philosopher Dawn McCance says it this way:

This future anteriority of the mirror stage trope distinguishes Lacan's specular subject, characterized by "anticipated belatedness" (Weber 1991, 10), from the conscious subject of metaphysical philosophy, Hegel's Selbst, for example, whose basis is a perfected present ... [It] means that the positioning of oneself as a unified ("phallic") subject within the Law-of-the-Father is an endeavor which inevitably fails. Aware of this failure, yet always attempting to cover it up, the signifying subject is beset by an inexorable anxiety, a disconcerting after-effect, an unrepresentable, contaminating and impossible to integrate, “after the fact [aprés coup], nachträglich” effect. For Lyotard, this after-effect bears such non-names as "the jews" and le différend. Lacan calls it jouissance. [1996:76-77]

Drusilla Cornell, reading Derrida and Levinas, explains how it is about justice:

As with Derrida, Levinas' conception of time has implications for his understanding of justice. For Levinas, Justice is messianic. The "avenir" is not just 
cuan_1153 can2008.cls June 13, $2012 \quad 14: 14$

the limit created by the aporias Derrida indicates, but instead inheres in the otherness of the Other that cannot be encompassed by any present system of ideality. The Other is other to the system. Incorporation into the system is the denial of the Other. Justice is sanctity for her "otherness." Nonencompassable by the system, the Other is also noncalculable. The right of the Other, then, is infinite, meaning that it can never be reduced to a proportional share of an already-established system of ideality, legal or otherwise. It is the Other as other to the present that echoes in the call to justice. [1992:137]

My point here is not to validate ethnography through philosophy. Instead, we can let philosophical teachings orient ethnography, so that ethnography produces something beyond philosophy. Theory thus operates as design logics, geared to enable ethnographic articulations that are truly creative, and therein a new kind of truth.

We surely need this. Working with toxics, I know especially well that we, as a society, need to invest in more data, more knowledge. I also know that we need new knowledge forms; that it is not just a matter of quantity.

Ethnography, it seems to me, can be designed to elicit these new forms. Not because the ethnographer is especially brilliant but because she knows how to listen, how to discern discursive gaps and risks, how to tolerate truly not knowing where one is headed. We are trained and positioned, funnily, to tolerate the unknown; we have an affordance for unimaginable futures.

It at times sobers me that I still work Spivak, Derrida, Homi Bhaba, and kin, not having moved beyond them. But perhaps this is because the kinds of openings they provided have of late been made elsewhere, or otherwise.

Perhaps it is ethnography that now does the work of "theory." Perhaps an ethnographic turn has followed the so-called linguistic turn of the 1980s.

The language turn, carried by texts like Writing Culture, directed our attention to the ways discursive and textual forms are constitutive of the real, directing what we see and say, and don't, and what counts as true, benefiting some, often at great cost to others. Language also came to be understood as a place of play and supplementarity, out of which quite unimaginable things could emerge. So ideas about systems that permit or even provoke play are not new. We haven't, however, really run with possibilities for building our own systems - experimental ethnographic systems - that leverage the ways we have come to understand language to work.

Such systems could take many forms - that of the book, the digital archive, or an event, among others — but what these systems would be after would be particular 
cuan_1153 can2008.cls June 13, $2012 \quad 14: 14$

subject effects - subjects able and willing - even wanting, desiring - to become party to new ways of thinking about and engaging a particular problem domain, a domain that we have analyzed ethnographically to understand the discursive gaps and risks that characterize it. What we would seek to engineer, then, would be something beyond understanding: a subject with a will to know, differently.

Such a subject could be called postmodern or specular. But here, in experimental ethnographic systems, there is ethnographic specificity. The systems are designed to unsettle the subjects and discursive forms with which they deal, in very specific ways. The Asthma Files are designed to respond to the particular discursive gaps and risk of the complex problem space in which asthma is dealt with. Michael Powell's effort to provoke new ways of thinking about the convenience store and the U.S. food system must be designed to attend to the habits and biases, discursive gaps and risks of that particular problem space. Ethnographic knowledge thus provides substantive logics, supplementing design logics drawn from what we traditionally think of as "theory."

This, it seems to me, is what would make ethnography "appropriate" to the historical conditions in which we find ourselves. Conditions characterized by massive violence, marginalization, and injustice; by environmental devastation and industrial recklessness; by stunning hubris and shrill ignorance. Conditions that cultivate a will not to know, not to engage, not to experiment.

It, of course, doesn't help that our politicians are defunding National Public Radio, public education and the sciences, and threatening to "padlock" the U.S. Environmental Protection Agency, ${ }^{18}$ an imperfect agency to be sure, but one that today can stand as a signal of what we cannot, or will not, deal with: problems that we don't know how to fix or even evaluate with currently available tools, problems that won't settle down, shifting as natural, social, economic and cultural systems continually play off one another. Really imagine it: a padlocked EPA, a society and culture that refuses to invest in complex problems, deeming all experiments necessary.

Ethnography can respond, reading these historical conditions with great care and solicitude, to stage encounters - in texts, online, in the street, in conference rooms - that are productively creative, creating space for something new to emerge, engineering imaginations and idioms for different futures, mindful of how very hard it is to think outside and beyond what we know presently.

Ethnography thus becomes creative — setting language games in motion, provoking different orderings of things, having patience for what we cannot yet imagine. Writing culture as a future anterior that draws us, with and away from 
Derrida, "toward an eschatology without philosophical teleology, beyond it in any case, otherwise than it" (1991:36-37). An ethnographic turn thus supplements the language turn.

\section{ABSTRACT}

This essay situates contemporary ethnography within late industrialism, a historical period characterized by degraded infrastructure, exhausted paradigms, and the incessant chatter of new media. In the sprit of Writing Culture, it calls for ethnography attuned to its times. It also calls for ethnography that "loops," using ethnographic techniques to discern the discursive risks and gaps of a particular problem domain so that further ethnographic engagement in that domain is responsive and creative, provoking new articulations, attending to emergent realities. Ethnographic findings are thus fed back into ethnographic engagement. This mode of ethnography stages collaboration with interlocutors to activate new idioms and ways of engaging the world. It is activist, in a manner open to futures that cannot yet be imagined. [ethnography, activism, collaboration, future anterior, discursive risks, ethnographic looping]

\section{NOTES}

1. For a recent review of the Bhopal disaster, see Ansell and Tinsley 2011.

2. See the Washington Post (Layton 2010) coverage.

3. I have worked with Chouhan to understand the Bhopal disaster since 1990. During my extended fieldwork in Bhopal in the early 1990s, the plant site was not accessible. It was accessible when I visited in December 2010, with Chouhan as my guide.

4. See details and the plan forward provided by the Electronic Take Back Coalition: http:// www.electronicstakeback.com/designed-for-the-dump/quickly-obsolete/.Toxipedia's entry on e-waste is also useful: http://toxipedia.org/display/toxipedia/Electronic+Waste+ (E-Waste).

5. A plan forward is laid out in "Water Works: Rebuilding Infrastructure, Creating Jobs, Greening the Environment," a report by Green for All. Download the report here: http://www.greenforall.org/resources/water-works/

6. Consider the kind of persona cultivated by and emblematic of the sciences, as described by feminist historian of science Evelyn Fox Keller in Reflections on Gender and Science (1985). They are obsessive compulsive in their desire for control, not so much of others as of oneself. Attention is subject to the same kind of control as the rest of behavior, leading to a focus so intensely sharp and restricted that it precludes peripheral vision and simply ignores the unusual, staying on narrow, established pathways for thought, going right by anything out of the way. Like tending a garden or forest with manicure scissors. My own research in the environmental sciences suggests that a different figuration of the scientist has emerged in recent decades. Keller's description of the subject effects of intensive expertise nonetheless remains important in thinking about late industrialism.

7. The slash used here refers readers to George Marcus's seminal article, Ethnography in/of the World System (1995).

8. For a historical reading, see Eric Schatzberg's "Technik Comes to America: Changing Meanings of Technology Before 1930" (2006).

9. See, for example, Vandana Shiva's (2002) writing on conflicts around the Kaveri River in South India. Anthropologist David Bond describes another instance of discursive risk: After the Exxon Valdez disaster in 1989, the U.S. National Oceanic and Atmospheric Administration (NOAA) committed to be being better prepared for ocean oil spills. And they were better prepared 
in the summer of 2010, when British Petroleum's Deepwater Horizon platform blew up and began gushing oil into the sea. NOAA was prepared, for a surface oil slick as in the Exxon Valdez case - not for a spill gushing up from a mile under the sea, out of control (Bond 2011).

10. Teresa de Lauretis, for example, emphasizes the need to understand both what systems say, and what they do not and cannot say. Understanding the gender effects of a social system, de Lauretis argues, demands "a movement back and forth between the representation of gender (in its male-centered frame of reference) and what that representation leaves out or, more pointedly, makes unrepresentable" (1987:25). The analyst must find or invent a way to move "between the (represented) discursive space of the positions made available by hegemonic discourses and the space-off, the elsewhere, of those discourses: those other spaces both discursive and social that exist, since feminist practices have (re-)constructed them, in the margins (or 'between the lines,' or 'against the grain') of hegemonic discourses and the interstices of institutions, in counterpractices, and in new forms of community" (1987:25). Also see Spivak (1987), Haraway (1988), and Cornell (1992).

11. This notion of looping recalls George Marcus's effort to vitalize "para-sites," now on-going at the Center for Ethnography at University of California, Irvine. Marcus's introduction to Para-Sites: A Casebook against Cynical Reason, a volume in the experimental Late Editions series, provides a preliminary articulation:[Para-sites are concerned with] forging spaces, sites, and even objects that facilitate alternative thinking by subjects who are deeply complicit with and implicated in powerful institutional processes in times of heightened consciousness of great social transformations. Our interest in how ambiguously alternative perspectives emerge amid moderately empowered people involved explicitly with major institutional powers has been a motivating component ... [The interest is in] "functionaries within important institutions ... who are attempting to come to terms with changing practices, opportunities, and selfdefinitions. The para-site is thus a space of excess or surplus in a subject's actions but is never fully controllable by him or her. The achievement is to be able to make and operate in such a space at all. This is cultural production as close to the skin of events and engines of change as possible. It is the kind of cultural work that critical scholars or ethnographers, on the lookout for "found" critical sensibilities, must ally with. [2000:5] Thanks to Kirk Jalbert for bringing this passage back to mind.

12. Derrida points to the aporia and paradox in the way hospitality requires one to be the master of the house or nation, a controlling agent, to lay the table and set the stage for encounters with foreigners and foreignness. To be hospitable, one has to have the power to host; one has to exercise control over the event. On must also, however, give up mastery, ownership, one's possessions, if the foreigner is really to come in, if hospitality is to be realized. So there is an impossibility at the heart of hospitality (Derrida 1999, 2001 Derrida with Dufourmantelle 2000). So, too, in ethnography. An experimental ethnographic system must be carefully staged, carefully controlled, to make way for something new to arrive. Here, too, there is an impossibility at the heart of it, but also a promise.

13. "Solicitude" has roots in solicit and soliciting. Derrida put solicitude at the heart of deconstruction:Structure is perceived through the incidence of menace, at the moment when imminent danger concentrates our vision on the keystone of an institution, the stone which encapsulates both the possibility and the fragility of its existence. Structure then can be methodically threatened in order to be comprehended more clearly and to reveal not only its supports but also that secret place in which it is neither construction nor ruin but lability. This operation is called (from the Latin) soliciting. In other words, shaking in a way related to the whole (from sollus, in archaic Latin "the whole," and from citare, "to put in motion"). [Derrida 1978:6]

14. Anthropologist Jerome Crowder works alongside this research group, and has introduced me. A brief description of their research is here: http://www.utmbhealth. $\mathrm{com} / \mathrm{wtn} /$ Page.asp?PageID=WTN000571. Examples of the visual analytics used by the group are accessible here: http://skbhavnani.com/DIVA/.

15. Our thinking about juxtapositional logic builds on James Clifford's article "On Ethnographic Surrealism" (1981).

16. Critically, the comparisons and juxtaposition in play in TAF are not generated by simple term matching or even by semantic webs that delineate when things mean the same thing, 
despite being said differently. In The Asthma Files, by digital design, comparison is animated by an our ethnographic questions, not by answers, such that answers are not expected in advance to be the same, or even pattered in a particular way. The Asthma Files system is thus built to be open-ended, rather than calculative. Comparisons are not generated by matching, but by questions that make things proximate even if vastly different. It is a different ways of ordering things, a way of staging collectivity that does not assume consensuses, or simple processes of communication. It (is meant to) embody a post structural, rather than Habermasian understanding of the way language and meaning production work.

17. See http://www.foodincmovie.com/.

18. I refer here to intentions articulated in the lead-up to the 2011 Republican Presidential Primary. For examples, see John Broders's coverage in the New York Times (2011; Broder and Galbraith 2011).

\section{REFERENCES CITED}

Ansell, Richard, and Andrew Tinsley

2011 "Bhopal's Never Ending Tragedy," The Environmentalist. October 13. http://www.environmentalistonline.com/article/2011-10-13/bhopal-snever-ending-disaster, accessed March 15, 2012.

Bateson, Gregory

1936 [1962] Naven: A Survey of the Problems Suggested by a Composite Picture of the Culture of a New Guinea Tribe Drawn from Three Points of View. Stanford: Stanford University Press.

Bhabha, Homi

1994 Articulating the Archaic: Cultural Difference and Colonial Nonsense. In

Bond, David The Location of Culture. Pp. 123-138. London: Routledge.

2011 The Science of Catastrophe: Making Sense of the BP Oil Spill. Anthropology Now 3(1):36-46.

Boykoff, Jules, and Maxwell Boykoff

2004 Journalistic Balance as Global Warming Bias: Creating Controversy Where Science Finds Consenus Extra! Fairness and Accuracy in Reporting (NovemberDecember). http://www.fair.org/index.php?page=1978 accessed March 15, 2012.

Broder, John

2011a Bashing EPA is New Theme in GOP Race. New York Times, August 17. http:// www.nytimes.com/2011/08/18/us/politics/18epa.html, accessed March 15, 2012.

Broder, John, and Kate Galbraith

2011b EPA is Longtime Favorite Target for Perry. New York Times, September 29. http: / /www.nytimes.com/2011/09/30/us/politics/epa-is-perrys-favoritetarget.html, accessed March 15, 2012.

Centre for Science and the Environment (CSE)

2009 Contamination of Soil and Water Inside and Outside the Union Carbide India Limited, Bhopal. CSE Laboratory Report. December. http://www.cseindia. org/userfiles/Bhopal\%20Report\%20Final-3.pdf, accessed March 15, 2012.

2011 Press Release: Dialogue on Air Pollution and Our Health. August 31. http://www.cseindia.org/content/cses-press-release-dialogue-air-pollutionand-our-health, accessed March 15, 2011.

Clifford, James

1981 On Ethnographic Surrealism. Comparative Studies in Society and History 23(4):539-564.

Clifford, James, and George Marcus, eds.

1986 Writing Culture: The Politics and Poetics of Ethnography. Berkeley: University of California Press. 
cuan_1153 can2008.cls June 13, $2012 \quad 14: 14$

Cornell, Drucilla

1992 The Philosophy of the Limit. London: Routledge.

de Lauretis, Teresa

1987 Introduction. In Technologies of Gender: Essays on Theory, Film and Fiction. Pp. 1-30. Bloomington: Indiana University Press.

Derrida, Jacques

1978 Writing and Difference. A. Bass, trans. Chicago: University of Chicago Press.

1990 Force of Law: The Mystical Foundation of Authority. Cordoza Law Review 11(5-6): 919-1045.

1991 At This Very Moment in This Work Here I Am. In Re-Reading Levinas. R. Bernasconi and S. Critchley, eds. R. Berezdivin, trans. Pp. 11-50. Bloomington: Indiana University Press.

1999 Adieu to Emmanuel Lévinas. Pascale-Anne Brault and Michael Naas, trans. Stanford: Stanford University Press.

2001 On Cosmopolitanism and Forgiveness. London: Routledge.

Derrida, Jacques (with A. Dufourmantelle)

2000 Of Hospitality. Rachel Bowlby, trans. Stanford: Stanford University Press

Fischer, Michael M. J.

2007 Culture and Cultural Analysis as Experimental Systems. Cultural Anthropology 22(1):1-65.

Fortun, Kim

2001 Advocacy after Bhopal: Environmentalism, Disaster, New Global Orders. Chicago: University of Chicago Press.

2003 Ethnography in/of/as Open Systems. Reviews in Anthropology 32(2):171190.

2011 Toxics Trouble: Feminism and the Subversion of Science. In Bodies in Space: Feminist Approaches to Nature and Materiality, Forum of Women's and Gender Studies, vol. 31. Elvira Scheich and Karen Wagels, eds. Pp. 234-255. Munich: Westfälisches Dampfboot.

Halsey, Ashley, III

2012 Billions Needed to Upgrade American's Leaky Water Infrastructure . Washington Post, January 2. http://www.washingtonpost.com/local/billionsneeded-to-upgrade-americas-leaky-water-infrastructure/2011/12/22/ gIQAdsE0WP_print.html, accessed May 22, 2012.

Haraway, Donna

1988 Situated Knowledge: The Science Question in Feminism and the Privilege of Partial Perspective. Feminist Studies 14(3):575-599.

Keller, Evelyn Fox

1985 Dynamic Objectivity: Love, Power and Knowledge In Reflections on Lancet Gender and Science. Pp. 115-126. New Haven, CT: Yale University Press.

2006 A Plea to Abandon Asthma as a Disease Concept. Lancet 368(9545): $1415-1416$.

Lanoo, Michael

2008 Malformed Frogs: The Collapse of Aquatic Ecosystems. Berkeley: University of California Press.

Layton, Lyndsey

2010 U.S. Regulators Lack Data on Health Risks of Most Chemicals. Washington Post, August 2. http://www.washingtonpost.com/wpdyn/content/article/ 2010/08/01/AR2010080103469.html, accessed March 14,2012.

Marcus, George

1995 Ethnography in/of the World System: The Emergence of Multi-sited Ethnography. Annual Review of Anthropology, 24, 95-117. 
Marcus, George

2000 Introduction. In Para-Sites: A Casebook against Cynical Reason. George Marcus, ed. Pp. 1-13. Chicago: University of Chicago Press.

McCance, Dawn

1996 Posts: Re Addressing the Ethical. Albany: State University of New York Press.

Outfoxed: Robert Murdoch's War on Journalism

2004 Robert Greenwald, dir. 77 min. Brave New Films. New York.

Perrow, Charles

1984 Normal Accidents: Living with High-Risk Technologies. New York: Basic

Rheinberger, Hans-Jorg

1998 Experimental Systems, Graphematic Spaces. In Inscribing Science: Scientific Texts and the Materiality of Communication. T. Lenoir, ed. Pp. 285-303. Stanford: Stanford University Press.

Ronell, Avital

2005 The Test Drive. Champaign: University of Illinois Press.

Schatzberg, Eric

2006 Technik Comes to America: Changing Meanings of Technology Before

Shiva, Vandana 1930. Technology and Culture 47:486-512

2002 Water Wars: Privatization, Pollution and Profit. Boston: South End.

Slade, Giles

2006 Made to Break: Technology and Obsolescence in America. Cambridge, MA: Harvard University Press.

Slater, Dashka

2012 The Frog of War. Mother Jones, January-February. http://motherjones. com/environment/2011/11/tyrone-hayes-atrazine-syngenta-feud-frog-

Sourcewatch endangered?page=1, accessed March 15, 2012

N.d. Monsanto's High Level Connections to the Bush Administration. Sourcewatch. http: / / www.sourcewatch.org/index.php?title=Monsanto's_High_Level_Connections_to_the_Bush_Administration, accessed March 15, 2012.

Spivak, Gayatri Chakravorty

1987 Other Worlds: Essays in Cultural Politics. New York: Methuen.

1993 Outside in the Teaching Machine. New York: Routledge.

SRI Consulting (for The Sierra Club, Earthjustice and ecoAmerica)

2006 The American Environmental Values Survey, 2006: American Views on the Environment in an Era of Polarization and Conflicting Priorities. SRI Consulting. October. http://ecoamerica.typepad.com/blog/files/ ecoAmerica_AEVS_Report.pdf, accessed March 15, 2012.

Tyler, Stephen A.

1986 Postmodern Ethnography. In Writing Culture: The Politics and Poetics of Ethnography. James Clifford and George Marcus, eds. Pp. 122-140. Berkeley: University of California Press.

Weber, Samuel

1991 Return to Freud: Jacques Lacan's Dis-Location of Psychoanalysis. Cambridge: Cambridge University Press.

Zota, Ami

2010 Oral Contraceptives Are not a Major Estrogen Source in Drinking Water. Environmental Health News, December 7. http: / /www.environmentalhealthnews. org/ehs/newscience/birth-control-not-major-estrogen-source-in-water, accessed March 15, 2011. 
cuan_1153 can2008.cls June 13, $2012 \quad 14: 14$

\section{Query}

Q1 Author: Marcus and Fischer 1986: This citation is not in the reference list. Please provide reference information. 